\title{
Ribotyping Identification of Thermophilic Bacterium from Papandayan Crater
}

\author{
Akhmaloka, A. Suharto, S. Nurbaiti, I N. Tika \& F. M. Warganegara \\ Biochemistry Research Division, Faculty of Mathematics and Natural Sciences, \\ Institut Teknologi Bandung, \\ Jl Ganesha 10 Bandung, Indonesia, email: loka@chem.itb.ac.id
}

\begin{abstract}
A few thermophilic bacteria were isolated from a hot spring located in Papandayan Crater, Garut. One of the organisms showed a well growth at temperature of up to $80^{\circ} \mathrm{C}$. Chromosomal DNA from the organism was isolated and used to amplify $16 \mathrm{~S}$ rRNA gene fragment. The gene was amplified by a set of universal primers (27F and $1492 \mathrm{R}$ ) resulting in a $1.5 \mathrm{~kb}$ DNA fragment. The gene was cloned and sequenced. The phylogenetic tree, homological analysis, and detailed comparison of the sequences showed that 16S rRNA gene sequence of the Papandayan isolate is unique compared to other known strains, however the sequence had closest similarities with Bacillus caldolyticus and Bacillus caldotenax.
\end{abstract}

Keywords: Bacillus caldolyticus; Bacillus caldotenax; Papandayan crater; thermophilic microorganism; 16S rRNA gene.

\section{$1 \quad$ Introduction}

Recently researches on thermophilic bacteria have extensively been carried out since these organisms offer many advantages either for development of basic sciences or for industrial applications. Thermophilic microorganisms can be used as sources of thermostable enzymes, which have high potential application for biocatalyst industries. The application of thermostable enzymes on biotechnological processes can reduce operational costs and increase the reaction rates thus increase the productivity (Aquilar et al 1998). The application of thermophilic microorganisms on the fermentation process also prevents contamination from other mesophilic bacteria. Extensive research on the genetics of thermophile have resulted in the modification of phylogenetic tree. Currently it is divided into three major groups, which are bacteria, archea and eukarya (Madigan and Mars 1997).

Thermophilic microorganisms are defined as groups of microorganisms which grown at a temperature above $45^{\circ} \mathrm{C}$, some of them still actively grow at $80^{\circ} \mathrm{C}$ (Madigan and Mars 1997). The organisms can easily be found in compost, hot spring, deep vents and other geothermal active regions (van den Burg 2003).

Received January 14, 2005, Revised June 15, 2006. 
Indonesia is one of the most tectonically active areas in the word with over 70 active volcanoes and has a substantial number of geothermal regions (Kusumadinata, 1979). Although Indonesia is diverse, terrestrial hydrothermal biotope posses a large number community of thermophilic bacteria, to date little effort has been made to characterize these thermophilic communities, hence an accurate identification of microorganisms is needed to be conducted. The different on the condition of environmental properties for each region can enable to isolate high heterogenous of thermopiles. Two methods, conventional (biochemical test) and ribotyping analysis are usually used to identify microorganism strains. However, 16S rRNA gene sequence analysis has been known and accepted to be an international acknowledged and effective method.

A few thermophilic microorganisms were isolated from hot spring around Indonesia, such as, Sileri hot spring, Dieng (Kim et al. 2001). The organism grew at a temperature of up to $85^{\circ} \mathrm{C}$ and employed the ribotyping analysis was identified as Thermoanarobacter yonseinsis sp. A few species of Bacillus were isolated from Cimanggu hot spring (Akhmaloka et al. 2000; Baker et al. 2001) grew at temperature of up to $83^{\circ} \mathrm{C}$. Geobacillus thermoleovorans was isolated from Wayang Crater (Indrajaya et al. 2003) grew at a temperature of up to $76^{\circ} \mathrm{C}$.

In this report we would like to describe the isolation and identification one of thermophilic microorganisms from Papandayan Crater, Papandayan Mount, Garut, West Java using 16S rRNA gene sequence analysis (ribotyping method).

\section{$2 \quad$ Material and Methods}

\subsection{Isolation and Bacterial Cultivation}

A set of $50 \mathrm{ml} 1 / 2 \mathrm{LB}$ media $(\mathrm{NaCl} 0.5 \%$, tryptone $0.5 \%$, and yeast extract $0.25 \%$ ) were prepared and sterilized. The media were then placed in a thermos box and transported to the field. Samples were taken from the hot spring of Papandayan Crater, Garut, West Java. $1 \mathrm{ml}$ of sediment-rich water recovered by a sterile syringe was transferred to each media flasks. The media were then immediately returned to the thermos box to maintain their temperature. All samples were returned to the laboratory within a period of hours and incubated with shaking at $70^{\circ} \mathrm{C}, 200 \mathrm{rpm}$. After 2 days $1 \mathrm{ml}$ of samples from the flask was transferred to fresh medium and incubated for further 48 hours at $70^{\circ} \mathrm{C}$. The well grown cultures were plated on solid $1 / 2$ LB media.

\subsection{Chromosomal DNA Extraction}

The DNA extraction method was based on the procedure of Klijn et al. (1991). Approximately $10^{9}$ cells from $2 \mathrm{ml}$ of culture medium were harvested by 
centrifugation and incubated in $200 \mu \mathrm{l}$ of lysozyme $\left(8 \mathrm{mg} \mathrm{ml}^{-1}, 10 \mathrm{mM}\right.$ Trish$\mathrm{HCl}$ ) for 1 hour at $37^{\circ} \mathrm{C}$. An equal volume of lysis buffer (2\% SDS, $200 \mathrm{mM}$ EDTA, proteinase $\mathrm{K} 0.8 \mathrm{mg} \mathrm{ml}^{-1}$ ) was added and the sample was incubated for 30 minutes at $55^{\circ} \mathrm{C}$. The sample was then precipitated with 2 volumes of ethanol and centrifuged to produce a pellet. The pellet suspended in $0.5 \mathrm{ml}$ sterile water, extracted with phenol-chloroform and re-precipitated with ethanol. The genomic DNA pellet was re-suspended in $50 \mu 1$ sterile water.

\subsection{Amplification and Cloning of 16S rRNA Gene}

Approximately $200 \mathrm{ng}$ of chromosomal DNA was amplified by PCR (initial denaturation 3 minutes at $94^{\circ} \mathrm{C}, 30$ cycles: 1 minute at $94^{\circ} \mathrm{C} ; 1$ minute at $48^{\circ} \mathrm{C} ; 1$ minute at $74^{\circ} \mathrm{C}$ followed by a single period at $72^{\circ} \mathrm{C}$ for 10 minutes; $1 \mathrm{U}$ Sigma Taq Polymerase) using bacterial 16S rRNA gene specific primers (Delong et al. 1993). $5 \mu$ volume of PCR product was visualized on $1 \%$ agarose gel electrophoresis and the rest was purified by ethanol precipitation. The purified PCR product were ligated into a pGEM-T (Promega) vector and used to transform competent Escherichia coli JM101. A few colonies of the transformants were analysis using restriction enzymes. The resulted fragments were visualised on $1 \%$ agarose gel electrophoresis. Samples with proper restriction pattern were chosen for sequencing.

\subsection{Sequencing and Sequence Analysis}

Recombinant plasmid from chosen transformants were isolated and purified using Qiagen mini-prep kit and sequenced using internal primers for 16S rRNA gene (Baker et al. 2001) and T7 and SP6 primers specific for pGEM-T vector (Table 1).

The resulted sequences were aligned using Seqman program from DNASTAR ${ }^{\circledR}$. The fragments of sequences were assembled and edited in Lasergene Seqman and consensus sequences were compared to other 16SrRNA gene in the GenBank using NCBI BLAST to obtain sequences with high homology to the fragments of sequences. Around 35 sequences were realigned and the phylogenetic tree from 28 related strains was constructed using MEGALIGN program from DNASTAR ${ }^{\circledR}$. 
Table 1 Primers were used in this study. Primers no 1 and 2 were used to amplify 16S rRNA; Primer no 3-9 were used to sequence the 16S rRNA gene.

\begin{tabular}{|c|c|l|}
\hline No. & Primer & \multicolumn{1}{c|}{ Sequences } \\
\hline 1. & $27 \mathrm{~F}$ & 5'-AGAGTTTGATC(A/C) TGGCTCAG-3' \\
2. & $1492 \mathrm{R}$ & 5'-GGTTAC(G/C) TTGTACCTGCCGGA-3' \\
3. & $357 \mathrm{~F}$ & 5'-TACGGGAGGCAGCAG-3' \\
4. & $803 \mathrm{~F}$ & 5'-GATTAGATACCCTGGTAG-3' \\
5. & $1114 \mathrm{~F}$ & 5'-GCAACGAGCGCAACCA-3' \\
6. & $909 \mathrm{R}$ & 5'-CCGTCAATTCATTTGAGT-3' \\
7. & $519 \mathrm{R}$ & 5'-GTATTACCGCGGCTGCTG-3' \\
8. & SP6 & 5'-GGGCGAATTGGGCCCGAC-3' \\
9. & T7 & 5'-TGCATAGCTTGAGTATTC-3' \\
\hline
\end{tabular}

\section{$3 \quad$ Results}

\subsection{Isolation and Morphology of Papandayan Isolate}

A few thermopiles bacteria were isolated from Papandayan Crater $(\mathrm{pH} \mathrm{3,78-}$ $90^{\circ} \mathrm{C}$ ). Isolation was performed by sampling sediment-rich water from the surface, center, and bottom of hot spring. More than 30 colonies were recovered on $1 / 2 \mathrm{LB}$ plate. The colonies were grown at a temperature of up to $80^{\circ} \mathrm{C}$. One colony (P1), showing the best growth, was chosen for further study.

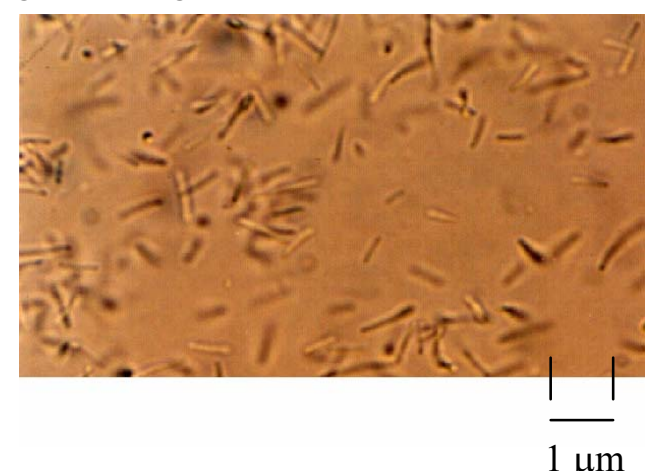

Figure 1 Morphology of the cells under Light Microscope with 1000X amplification.

Morphological observation of P1 cell under light microscopy (Olympus BH2) showed that the cell is a rod shaped bacteria (Figure 1). Further analysis using gram-staining method proved that the isolate was a gram-positive bacterium. 


\subsection{Amplified DNA Fragment}

$16 \mathrm{~S}$ rRNA gene amplified with $27 \mathrm{~F}$ and $1492 \mathrm{R}$ primers from $\mathrm{P} 1$ isolate was observed on agarose gel electrophoresis. The result showed an amplicon band with the size of $1.5 \mathrm{~kb}$ respectively (Figure 2). The DNA fragment was ligated on pGEM-T vector and the recombinant vector was used to transform E. coli JM101. Quick analysis of the vector using agarose gel electrophoresis showed that the migration of recombinant vectors were slower than that of original pGEM plasmid (data not shown). This suggested that recombinant vectors harbor DNA inserts.

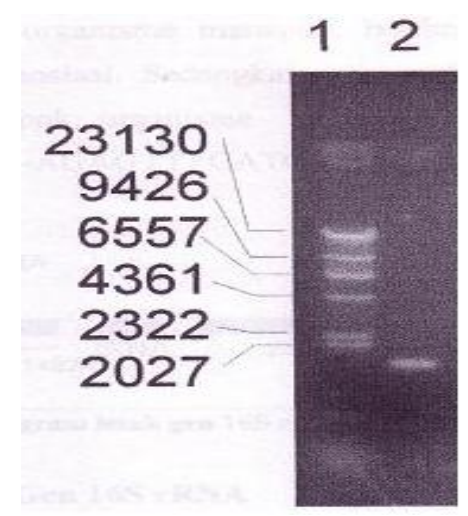

Figure 2 Electrophoregram of PCR product. Lane 1 shows $\lambda$ DNA cut by HindIII; lane 2 shows PCR product amplification.

Further characterization was performed by restriction analysis using SalI and PstI restriction enzymes. The resulted DNA fragments analysis using agarose gel electrophoresis and the results confirmed that the vector contained $16 \mathrm{~S}$ rRNA gene (data not showed).

\subsection{Sequences and Homology of DNA Fragment}

The chosen plasmid from the result of restriction analysis was sequenced based on the strategy showed on Figure 3. At least two independent sequences were used to confirm the correct sequence of the fragment. The complete sequence of the fragment was appeared to contain 1502 base pairs.

This sequence was compared to available sequences data on the GenBank and the results showed that the sequence has close homology to all 16S rRNA genes. Phylogenetic analysis of the sequences was conducted through comparison with other 27 best homologous sequences (Figure 4) resulted in Papandayan isolate being closest in homology to $B$ caldolyticus. The 
extremophiles of Bacillus and Geobacillus showed $99 \%$ identical sequences out of nineteen closest homologies (Table 2).

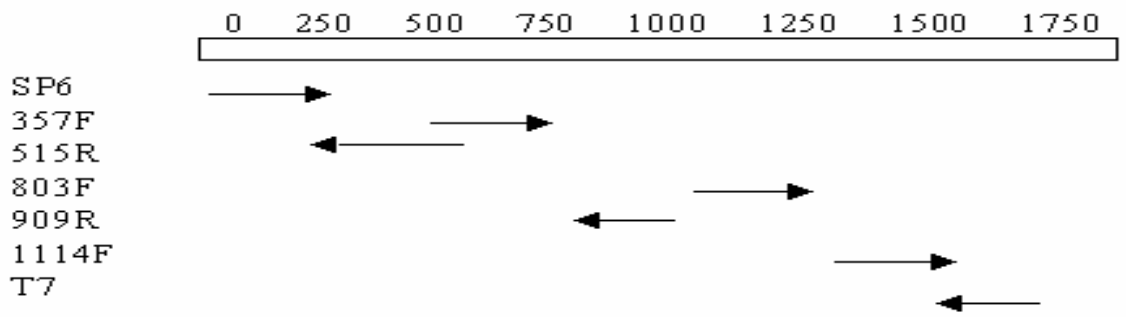

Figure 3 Strategy for sequencing the whole 16S rRNA gene, SP6 and T7 were external primers of the gene.

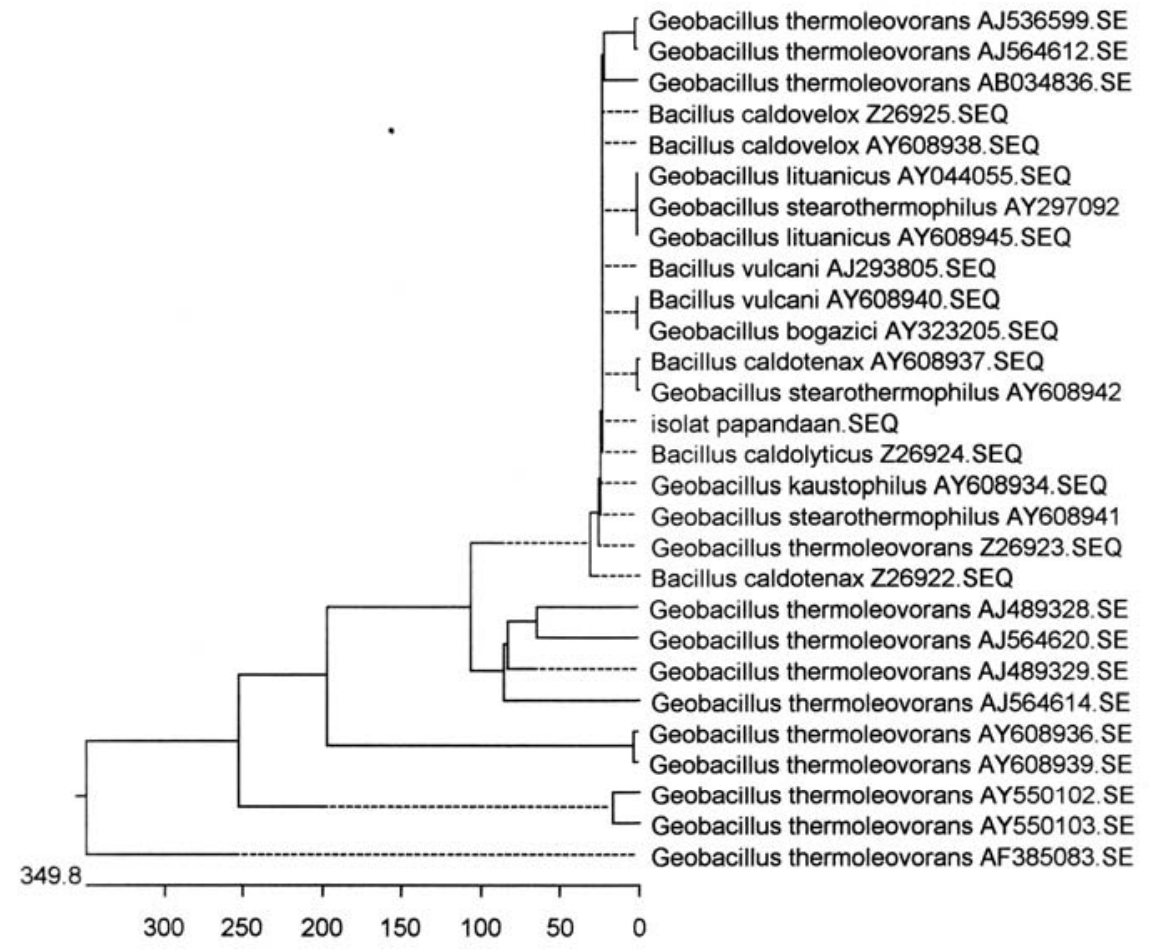

Figure 4 The phylogenetic tree of Papandayan isolate.

Further analysis by comparing the 16S rRNA gene sequences among the highest homology (Table 2) showed few differences at the position of the conserved region (Table 3). The nucleotide sequence at position 508 (U3 region) for $B$. vulcani AJ293805, B. caldovelox AY608938, Z26925, and G. thermoleovorans 
AJ564612 was A while for other organisms, including Papandayan isolate the base was G. The nucleotide sequence at position 815 (U4 region) for all strains was $\mathrm{T}$ with an exception of A for G. thermoleovorans Z26922. While at sequence position 1379 (U7 region), G. lituanicus AY608945 the nucleotide was $A$, and $\mathrm{G}$ in other organisms. More differences on 16S rRNA genes from the strains occurred in non-conseved sequence regions regions (Table 3). There were two bases, A at sequence position 1167 and T at 1186, on Papandayan isolate differed from all strains examined, however these positions lied in the non-conserved region (Table 3).

\section{Discussion}

Identification of thermophilic bacterium isolated from Papandayan Crater was performed through analysis of 16S rRNA gene sequence. The successful result of DNA fragment insertion into pGEM vector was confirmed by restriction analysis using SalI and PstI restriction enzymes. The result was also confirmed confirmed by the analysis of the fragment.

Table 2 Best nineteen homologies with 16S rRNA gene of Papandayan isolate.

\begin{tabular}{|c|l|c|l|}
\hline No & \multicolumn{1}{|c|}{ Organisms } & $\begin{array}{c}\text { \% } \\
\text { Identities }\end{array}$ & \multicolumn{1}{|c|}{$\begin{array}{c}\text { Accession } \\
\text { No. }\end{array}$} \\
\hline 1. & Bacillus caldotenax & $99 \%$ & AY608937 \\
2. & Geobacillus kaustophilus & $99 \%$ & AY608934 \\
3. & Geobacillus stearothermophilus & $99 \%$ & AY608942 \\
4. & Geobacillus thermoleovorans & $99 \%$ & AJ536599 \\
5. & Bacillus vulcani & $99 \%$ & AY608940 \\
6. & Geobacillus thermoleovorans & $99 \%$ & AY608936 \\
7. & Geobacillus thermoleovorans & $99 \%$ & Z26923 \\
8. & Geobacillus stearothermophilus & $99 \%$ & AY608941 \\
9. & Bacillus caldotenax & $99 \%$ & Z26922 \\
10 & Geobacillus thermoleovorans & $99 \%$ & AY608939 \\
11 & Bacillus caldolyticus & $99 \%$ & Z26924 \\
12 & Geobacillus lituanicus & $99 \%$ & AY608945 \\
13 & Geobacillus thermoleovorans & $99 \%$ & AJ564612 \\
14 & Geobacillus thermoleovorans & $99 \%$ & AJ564614 \\
15 & Bacillus vulcani & $99 \%$ & AJ293805 \\
16 & Geobacillus thermoleovorans & $99 \%$ & AY550103 \\
17 & Geobacillus thermoleovorans & $99 \%$ & AF385083 \\
18 & Geobacillus thermoleovorans & $99 \%$ & AJ489329 \\
19 & Geobacillus thermoleovorans & $99 \%$ & AJ564620 \\
\hline
\end{tabular}




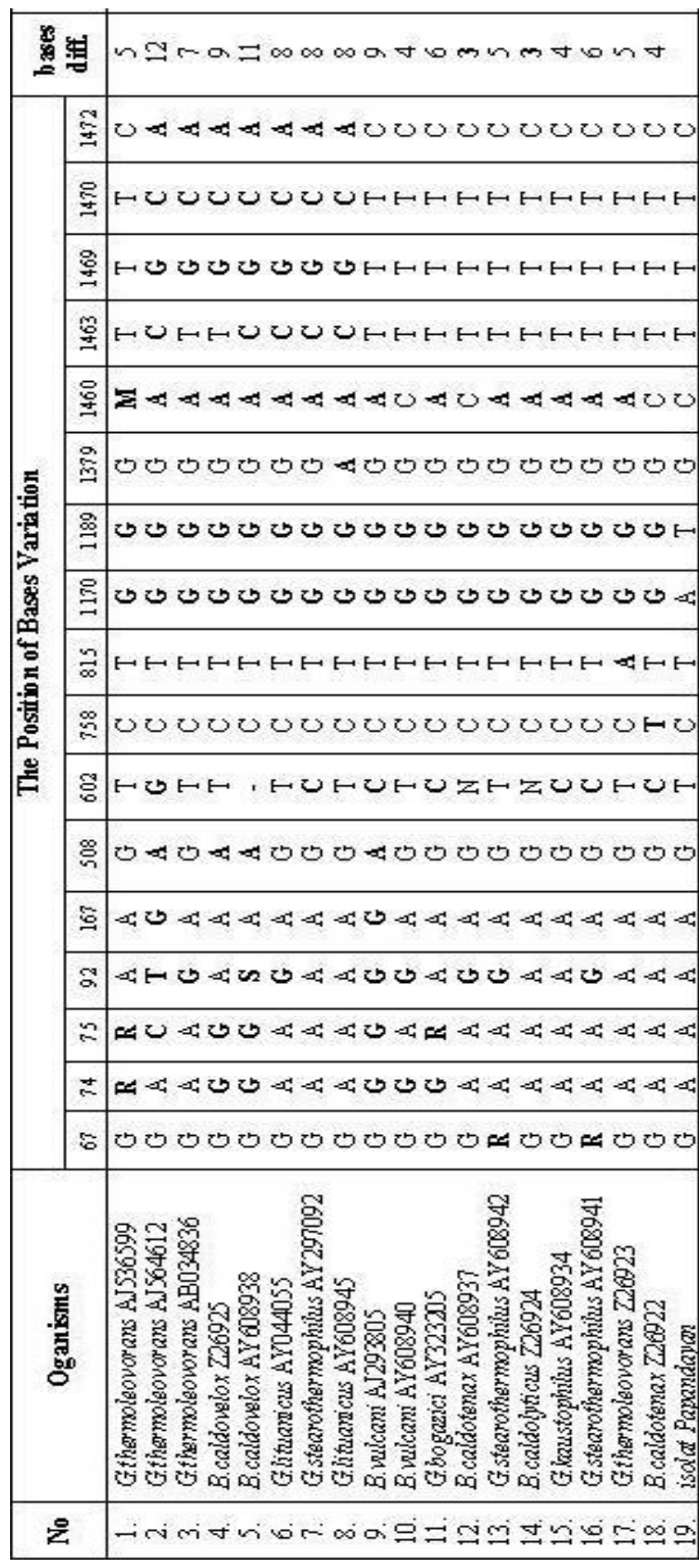


Analysis using the BLAST Program (Atschul et al. 1997) resulted in sequence that had close homology to all 16S rRNA genes available on the GenBank. This confirmed that the amplicon was a part of 16S rRNA gene. 19 closest $(99 \%$ identities sequences) homologies of the isolate appeared to the extreme thermophilic genus of Bacillus or Geobacillus (Table 2). Close homology of the isolate to extreme thermophile from the genus of Bacillus and Geobacillus was also supported by morphological identification (Figure1) and ability of the isolate to grow at a range of temperature between 45 to $80^{\circ} \mathrm{C}$ (data not shown). Extreme thermophile of Bacillus, such as B. caldotenax, B. caldovelox, B. caldolyticus, $B$. thermoleovorans and $B$. stearothermophilus were able to grow at temperature range of $45-80^{\circ} \mathrm{C}$ (Friedman, 1992). A large collection of rod shaped bacteria (Akhmaloka et al. 2000; Baker et al. 2001; Indrajaya et al. 2003) may be due to the media or technique used on the sampling and the treatment of the sample during cultivation in laboratories. Bacillus was known as dominance bacteria on the environment due to its ability to form endospore, while other bacteria need very specific condition to struggle for growth.

Phylogenetic tree was constructed by ClustalW methode from MEGALIGN program of DNASTAR $\AA$, using 27 nucleotide sequences that displayed close homology from the BLAST program. Papandayan isolate showed closest similarity to B. caldolyticus Z26924, B. caldotenax AY608937, and G. stereothermophilus AY608942 (Figure 4). Although Papandayan isolate showed closest similarity to the above strains, it was hard to differentiate among other strains as mentioned on the Table 2, since all of them were $99 \%$ identical with the 16S rRNA gene sequences. However, the result from detailed comparison with the 16S rRNA gene sequences showed that the possibility of Papandayan isolate being identical with B. vulcani AJ293805, B. caldovelox AY608938, Z26925, and G. thermoleovorans AJ564612, G. thermoleovorans Z26922, G. lituanicus AY608945 was unlikely since they have differences in the conserved region. Results of detailed comparison between Papandayan isolate with B. caldolyticus Z26924, B. caldotenax AY608937, and G. stereothermophilus AY608942 showed that B. caldolyticus Z26924, B. caldotenax AY608937 showed that there were only 3 different bases with Papandayan isolate, while G. stereothermophilus AY608942 had 5 base differences. Based on all of the above results there is a possibility that Papandayan isolate is a unique strain since different strains such as $B$. caldolyticus Z26924, and B. caldotenax AY608937 were differentiated by two base variation only. While Papandayan isolate had at least 3 base differences with other known strains. 


\section{Acknowledgements}

Akhmaloka gives thanks to the QUE Project Department of Chemistry ITB and Third World of Academic Sciences for supporting this work.

\section{References}

1. Aguilar, A., Ingemansson, T., Magnien E., Extremophile microorganisms as cell factories: support from the European Union. Extremophiles 2, 367-373 (1998).

2. Madigan, M.T., Marrs, B.L., Extremophiles. J Sci Am 276, 66-71 (1997).

3. Van de Burg B., Extremophiles as a source for novel enzymes. Curr Opinon in Microbiol 6, 213-218 (2003).

4. Kusumadinata, Catalogue of References on Indonesian Volcanoes with Eruptions in Historical Time. Department of Mining and Energy (1997).

5. Kim, B.C., Grote, R., Lee, D.W., Antrankian, G., Pyun, Y.R., Thermoanaerobacter yonseiensis sp. A novel extremely thermophilic, xylose-utilizing bacterium that grows at up to $85^{\circ}$ C. Int J Syst Evol Microbiol 51, 39-1549 (2001).

6. Akhmaloka, Tika, I N., Pamono, H., Sidumarta, M., Isolation and characterization of DNA Polymerase from local thermophilic microorganisms. JMS 4, 5-343 (2000).

7. Baker, G.C., Gaffar, S., Cowan, D.A., Suharto, A.R., Bacterial community analysis of Indonesian hot spings. FEMS Microbiol Lett 200, 3-109 (2001).

8. Indrajaya, Warganegara, F.M. \& Akhmaloka, Isolation and Identification of Thermophilic Microorganism from Wayang Crater. Jurnal Mikrobiologi Indonesia 8, 53-56 (2003).

9. Klijn, N., Weerkamp, A.H., De Vos, W.M., Identification of mesophilic lactic acid bacteria by using polymerase chain reaction-amplified variable regions of $16 \mathrm{~s} r A$ and specific DNA probes. J Appl Environ Microbiol 57, 3390-3391 (1991).

10. Delong, E.F., Franks, D.G., Aldredge, A.L., Phylogenetic diversity of aggregate-attached vs. free-living marine bacterial assemblages. Limnol Oceanol 38, 924-934 (1993).

11. Altschul, S.F., Gapped BLAST and PSI-BLAST: a new generation of protein database search programs. Nucleic Acids Re 25, 3389-3402 (1997).

12. Friedman, Thermophilic microorganisms. Encyclo Microbiol 4, 217-229 (1992). 